2

3

4

5

6

14

15

16 Gembloux, Belgium) for the selection of study sites.

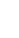

\title{
Horizons and humus forms in beech forests of the Belgian Ardennes
}

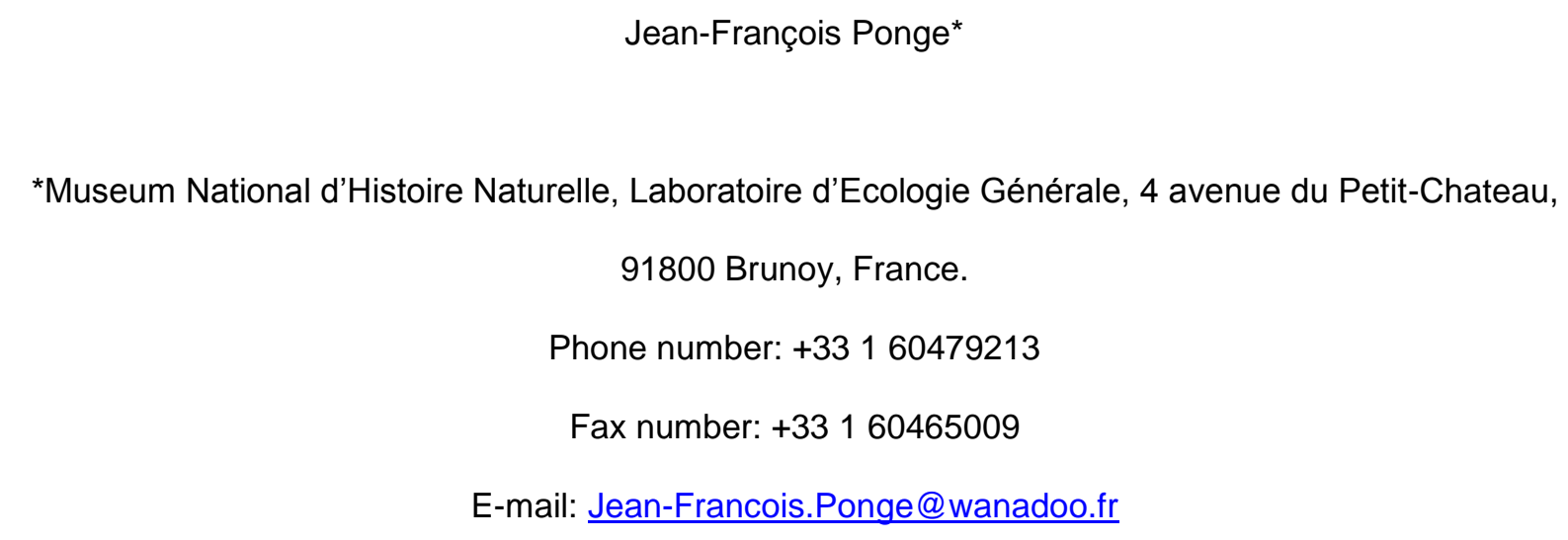

\section{ACKNOWLEDGEMENTS}

17 


\section{Horizons and humus forms in beech forests of the Belgian Ardennes}

\section{ABSTRACT}

5

6 Forest soil organic horizons are named on the basis of visual observations made directly in the field, thus 7 this is often subjective. Humus form horizons were compared in thirteen beech stands (Fagus sylvatica

8 Ehrh.) of the Belgian Ardennes (western Europe) embracing a wide range of ecological conditions, in 9 order to find more objective bases for their classification. We used a semi-quantitative micromorphological 10 method for the description of horizons, and a multivariate method for data analysis. These methods 11 helped to discern objective discontinuities between Oi, Oe and Oa horizons, adding new criteria for their 12 characterization, such as the root system of trees. Within these horizons, transitions between sub13 horizons are gradual, thus do not lie on clear-cut criteria. The transition between Oa and A horizons was 14 also gradual. The composition of $\mathrm{Oa}$ and $\mathrm{A}$ horizons varies according to humus form. The vertical 15 distribution of soil organisms and their vertical movements were considered the origin of discontinuous 16 and continuous processes taking part in the transition from one horizon to another. The observation of 17 horizons under a dissecting microscope may help to find more reliable bases for their nomenclature, even 18 without the use of costly soil sections. 


\section{INTRODUCTION}

2

Since the pioneering work of Müller (1889), who described two basic humus forms, mull and torf, beneath Danish beech forests, on the basis of microscopic observations, there have been many attempts to classify humus profiles in forest soils. Different horizons or sub-horizons are generally recognized within the O Horizon (Brady, 1984) or Ao (Duchaufour, 1997) horizon. Although discrepancies concerning the terminology of these strata exist, three main strata are recognized, Oi (entire leaves), Oe (fragmented leaves), and $\mathrm{Oa}$ (holorganic faecal pellets). Differences in the development of these horizons, together with structure and chemical properties of the underlying A horizon, allow recognition of three main humus forms, now called mull, moder, and mor (Klinka et al., 1981; Delecour, 1983; Green et al., 1993; Brêthes et al., 1995; Jabiol et al., 1994, 1995). The mor humus form, together with dysmoder (moder with a thick H stratum), has been also called raw humus (Kubiëna, 1953; Delecour, 1980). The recognition of biological processes taking place in the development of humus profiles (Hartmann, 1965; Zachariae, 1965; Bal, 1982) suggested that some features, such as compaction of the soil matrix, deposition of faecal pellets, skeletonization of leaves or tunnelling of needles, are the direct result of soil faunal activity. Thus, as for most biological processes, the transition from one horizon to another should be considered discontinuous, due to tolerance limits and food and habitat preferences of soil organisms.

西

common; however, the existence of clear-cut changes between one horizon and another has been poorly demonstrated through quantitative or semi-quantitative morphological data. Federer (1982) pointed out that simple remeasurements of thickness of forest soil horizons may lead to false conclusions if done by two individuals. Discrepancies between field and laboratory observable features of horizons have been reported (Bernier et al., 1993). This may indicate that some morphological criteria used for the definition of organic horizons are inadequate or difficult to employ with accuracy in the field. This is particularly true for the transition from Oa to A horizons and for subdivisions which have been recognized within Oi and Oe horizons (Babel, 1971). 
1

2

3

4

5

6

7

8

9

10

11

16

5

In the present study, our purpose was to determine whether the transition from one organic horizon to another is a continuous or, rather, a step-by-step process, with sharp delineations in horizon properties. In doing so, we addressed the question as to whether horizons exhibit true emergent properties and have not been created by soil scientists for only classification purposes.

\section{MATERIAL AND METHODS}

\section{Nomenclature}

Comparable organic horizons have several different names depending on the taxonomic system in use. The commonly used nomenclature of Brêthes et al. (1995) corresponds to USDA nomenclature as follows: $\mathrm{OL}$ equals $\mathrm{Oi}, \mathrm{OF}$ equals $\mathrm{Oe}$, and $\mathrm{OH}$ equals $\mathrm{Oa}$. These horizons correspond to $\mathrm{L}, \mathrm{F}$ and $\mathrm{H}$ horizons, respectively, recognized by Hesselmann (1926) and later refined by Babel (1971).

The classification of humus forms by Brêthes et al. (1995) was used in this study. It is not based on a strong relationship between the features $\mathrm{O}$ and $\mathrm{A}$ horizon, as this is the case in other classifications. For instance, a crumby A horizon (typical of mull) may coexist with a thick O horizon (typical of moder). Some humus forms, such as hemimoder and amphimull, were described by other authors as mull-moder (Duchaufour, 1997) or mull-like moder (Kubiëna, 1953; Delecour, 1980, 1983). A hemimoder means a moder humus form (A horizon with organic matter juxtaposed to mineral matter) without any Oa horizon. An amphimull means a mull humus form (A horizon with organo-mineral assemblages) with a distinct $\mathrm{Oa}$ horizon.

The nomenclature of soil types used in this study followed the FAO-UNESCO classification (Driessen and Dudal, 1991). Cambisols and podzols correspond to Inceptisols and Spodosols, 
respectively, in USDA Soil Taxonomy (Brady, 1984). Nomenclature of plant species followed Rameau et al. (1989). humus forms (Table 1). Beech (Fagus sylvatica) forests were chosen because of their wide distribution and the need for a wide range of environmental conditions, in particular soil and climate, without strong variation in the composition of litter. All studied sites were located on nutrient-poor geological substrates (schists, graywackes, quartzites) ranging from Cambrian to Devonian age. Altitude and related regional factors (climate, mineral richness of parent rock) were found to be the main source of variation of soil animal communities, humus forms and site quality over the studied range (Ponge et al., 1997). Results of litter and soil chemical analyses were also reported in the aforementioned paper.

These profiles were chosen to represent the range of observed within-site variation of humus forms. Sampling was completed in June 1989. Preparation of the samples $(5 \times 5 \mathrm{~cm}$ section monoliths) was carried out according to the method of Bernier and Ponge (1994), except that only the top $1 \mathrm{~cm}$ of the A horizon was sampled. Horizons were separated in the field on the basis of variation visible to the naked eye, without reference to any a priori classification. Afterwards, they were classified into Oi, Oe, and Oa horizons according to the abovementioned field criteria, and numbered according to their order from the top to the bottom of a given horizon, i.e. Oi1, Oi2, Oi3, Oe1, Oe2, etc... All 172 horizons were immediately immersed in ethyl alcohol then transported to the laboratory. The composition of each horizon was analyzed by observing the soil matrix in alcohol under a dissecting microscope. No attempt was made to quantify the volume or mass of each category. Rather, we used the following visual semi-quantitative 
coding of the abundance of a given category in a given horizon:

2

3

4

5

6

7

8

9

10

11

12

13

14

15

16

17

18

19

20

21

22

23

24

25

26

27

$\begin{array}{ll}\text { absent } & 0 \\ \text { present but scarce } & 1 \\ \text { present and common } & 2 \\ \text { present and dominant } & 3\end{array}$

\section{Multivariate analysis} methods.
A total of 185 categories were recognized. Most of them were plant litter, in varying degrees of decomposition or comminution by fauna. Animal faeces were classified according to the corresponding animal group, their degree of comminution by other animals, and their degree of connection with uneaten plant categories. Animals were counted and classified into broad groups.

Correspondence analysis (Greenacre, 1984) was used to give an overall picture of affinities and differences between horizons and/or categories. This method, using the chi-square distance, allows horizons and categories to be simultaneously projected on factorial axes, thus groups of samples could be directly associated with groups of categories. As was theoretically developed by Benzécri (1973), this method has been refined for particular purposes such as community gradient analysis [detrended correspondence analysis (Hill and Gauch, 1980)] or the study of community-environment relationships [canonical correspondence analysis (Ter Braak, 1987)]. Here, our purpose was to analyze the structure of a data matrix (the composition of horizons) without any a priori hypotheses concerning their relationships with environmental factors and with more than one single factor suspected to result from the analysis. Additional (passive) variables were used to help interpretation of the factorial axes and not to quantify causal relationships. Thus, we used the approach of original correspondence analysis, that was devised to evaluate global patterns underlying complex data matrices, and not that of the aforementioned derived 
1

Matrices were analyzed so that horizons were observations (rows) and categories were active variables (columns). Animal groups, horizon names, humus form names, phytosociological types, and altitude were added as passive variables. They had no influence on the results, but they were projected on factorial axes as the active variables.

Categories were coded and counted as indicated above. Animal groups were recorded as total counts. Horizons, humus forms and phytosociological types were coded as 1 when a given horizon (row) belonged to a given category (column), 0 when not. Altitude was recorded in meters. All variables (active and passive) were standardized with unit variance and a mean of 20 . This allowed contributions to factorial axes to be proportional to factorial coordinates and data of a different nature, such as counts, semi-quantitative coding and measurements, to be included in the same analysis (Ponge and Delhaye 1995). In the case of altitude, high elevation and low elevation were distinguished. Standardized altitude values (high elevation) were complemented to 40 in order to create a new variable, varying in an opposite sense (low elevation). The new variable had similar mean (20) and standard deviation (1). Following this procedure, already used by Ponge and Delhaye (1995), the range of elevation values was described by two symmetrical points.

\section{RESULTS}

\section{Composition of the humus profile}

We analyzed first the total 172 horizons and 185 categories. Only axes 1 and 3 were considered for the global description of humus horizons. Axis 2 was neglected, because it isolated only one horizon (Oe1 in the second profile studied in site 16), which was characterized by the development of the root system of hair-grass (Deschampsia flexuosa) at the inside of decaying plant fragments. This development 
was not apparent in other humus profiles, due to scarcity of ground vegetation, and we preferred to discard the corresponding axis rather than to discard this horizon from the analysis.

The projection of horizons in the plane of axes 1 and 3 (Fig. 1) indicated that they could be classified into three groups, corresponding to $\mathrm{Oi}, \mathrm{Oe}$, and $\mathrm{Oa}+\mathrm{A}$ horizons, respectively. All horizons sampled did not fall exactly in each of the three branches depicted by the plane of axes 1 and 3 . This does not indicate that $\mathrm{Oi}, \mathrm{Oe}$, and $\mathrm{Oa}+\mathrm{A}$ horizons were poorly differentiated on the basis of their composition. Rather, this phenomenon indicates that a few horizons had been badly classified in the field; correspondence analysis revealed that they had more points in common with another group than with their own group. Differences between $\mathrm{Oa}$ and $\mathrm{A}$ horizons were negligible when compared with differences between Oi and Oe horizons. Oa and A horizons did not exhibit distinct branches. In addition, differences within each of the $\mathrm{Oi}$, Oe or Oa horizons were negligible compared to differences between these horizons. each horizon or group of horizons by its composition (Table 2). The Oi horizon was characterized by entire leaves of beech at varying stages of fungal conditioning and small recently fallen tree categories such as bud scales, male flowers, and twigs. Smears of faecal material, holorganic or organo-mineral, were observed at the surface of some beech leaves. A laminated mixing of leaf fragments and faeces of litter-consuming enchytraeids, which we called "sandwich material", together with plant categories such as male flowers of beech, grass stems, twigs, at some stage of decomposition, was characteristic of the Oe horizon. The presence of beech petioles and nerves, mycelial strands and living bases of wood-rush (Luzula forsteri) was also noticeable. Both Oa and A horizons were characterized by dead or senescent

24 fine roots, living and dead woody roots, old (compacted) holorganic enchytraeid faeces, and fragments of parent rock (both intact or weathered). Charcoal was also present in this group of horizons. Sclerotia of the mycorrhizal ascomycete Cenococcum geophilum also occurred. 
Living fine roots of beech and faeces of litter-consuming enchytraeids were placed in an intermediate position between the Oe horizon and the $\mathrm{Oa}+\mathrm{A}$ horizons. This indicated that they were present in all of these horizons and, thus, they did not help in differentiating among horizons. Maple (Acer pseudoplatanus) and ash (Fraxinus excelsior) plant materials were different. These categories only occurred at one site (100) which was characterized by an intense earthworm activity, with abundant cast deposition within the Oi horizon (Fig. 1). The projection of corresponding samples was influenced by the presence of organo-mineral material (typical of the A horizon of mull humus) together with categories typical of the Oi horizon, which influenced in turn the position of the abovementioned ash and maple categories.

Oa and A horizons, which were considered as diagnostic horizons for the separation of mull versus moder humus forms (Delecour, 1983; Brêthes et al., 1995), were not clearly separable on the basis of composition as revealed by the use of a dissecting microscope. In order to reveal possible variation in the composition of these horizons, we analyzed separately Oa and A horizons (partial analysis). The projection of horizons in the plane of axes 1 and 2 (Fig. 2) separated Oa and A (classified by field observation), but with a high degree of overlapping. This indicated that the distinction between $\mathrm{Oa}$ and $\mathrm{A}$ horizons that had been made in the field $(\mathrm{Oa}=$ holorganic, $\mathrm{A}=$ organo-mineral $)$ did not reflect true composition. The projection of some passive variables such as humus form, altitude and phytosociological type (Fig. 3) helped to establish a link between Axis 2 of partial analysis and ecological conditions prevailing in the studied sites. Mull humus forms were on the negative side of Axis 2; moder humus forms were placed on the positive side of Axis 2 .

The composition of $\mathrm{Oa}$ and $\mathrm{A}$ horizons, as indicated by the projection of categories in the plane of axes 1 and 2 of partial analysis (Appendix 2), depended on the humus form. The Oa horizon of moder humus forms (eumoder, hemimoder and dysmoder) was mostly characterized by compacted holorganic faeces of enchytraeids, different plant organs hard to decay, bundles of skeletonized beech leaf fragments, living woody roots of beech, and dead black mycorrhizae of beech produced by Cenococcum 
geophilum. The upper part of the A horizon of mull humus forms (oligomull, amphimull, dysmull) was mostly characterized by organo-mineral earthworm faeces, milliped faeces, intact stones, beech leaves skeletonized by macrofauna or mesofauna and categories belonging to ground vegetation such as the root system of grass species or bleached leaves of wood-sorrel (Oxalis acetosella). The Oa horizon of amphimull shared many features with the A horizon of the mull group (indicated by its position on the negative side of Axis 2). The A horizon of the moder group was placed in an intermediary position (not far from the origin, on both sides of Axis 2), thus without characteristic features distinguishing both the horizon and the humus form.

\section{Distribution of soil animals}

1

(1)

Animal groups found during the dissection of humus horizons (Table 3) were projected as passive variables in the plane of axes 1 and 3 of total analysis (Fig. 4). Comparison with the position of horizons (Fig. 1) revealed that the Oi horizon was very poor in fauna at the time of sampling (June), no animal group being placed far from the origin in the direction of the Oi Ihorizon (see also Table 3). The Oe horizon was characterized by mites other than Platynothrus peltifer (MIT, ORI, PHT) and springtails (SPR), the latter being present at a greater depth than the former as ascertained by the respective position of corresponding points along Axis 1 . The only group that characterized the $\mathrm{Oa}+\mathrm{A}$ horizons was enchytraeids (ENC). Enchytraeids mainly characterized the Oa horizon, as it appeared from the comparison of $\mathrm{Oa}$ and $\mathrm{A}$ horizons (Fig. 5, Table 3). Most fauna (here mostly mesofauna) were concentrated in the Oe and Oa horizons, the most abundant group being enchytraeids, followed at a far lower level of abundance by mites and springtails, with an increasing preference for deeper horizons at the time of sampling in the order mites < springtails < enchytraeids.

4


The existence of a transitional horizon between typical $\mathrm{Oa}$ and $\mathrm{A}$ horizons, due to a progressive enrichment in mineral particles of the Oa horizon, has been suggested by Delecour $(1980,1983)$. He even considered it as a characteristic feature of the humus forms belonging to the moder group, rather than the accumulation of holorganic faeces in Oe and Oa horizons which is commonly used to define moder humus (Klinka et al., 1981; Green et al., 1993, Duchaufour, 1997). This feature is also used in the classification of forest humus forms by Brêthes et al. (1995) where the A horizon of moder humus forms is considered to be made of holorganic faeces juxtaposed to mineral particles, without true incorporation of organic matter to mineral matter. This composition can be achieved by the vertical movements of small animals carrying mineral particles onto their tegument and depositing them, together with faeces, in the course of their wandering between food sources (Oe horizon) and refuges (Oa and A horizons). In moder humus forms, where no other agent mixes organic matter with mineral matter, this behaviour is typical of animals with a sticky tegument such as enchytraeid worms (Ponge, 1991), whose daily vertical movements of several centimeters are well-known (Springett et al., 1970). In this case the gradual passage from the $\mathrm{Oa}$ to the $\mathrm{A}$ horizon can be interpreted as an active (biological) diffusion process, the source of organic matter being decaying litter, which is actively consumed by these animals and humified (Ponge, 1991), and the source of mineral matter being underlying mineral horizons. As has been observed in other studies (Zachariae, 1965; Ponge, 1991) enchytraeids also consume faeces of other animals such as oribatid mites. As they live deeper (on average) than other litter-dwelling animals (Table 3) they progressively incorporate faeces of litter-consuming animals into their own faecal material. This may explain why the Oa horizon of moder humus forms appears mainly made of compacted enchytraeid faeces and unconsumed material rather than remains of the activity of all litter-feeding animals. They also ingest silt particles (unpublished data), and carry them onto their tegument (Ponge, 1988). This pattern may lead to the observed soft transition from Oa to A horizons.

The presence of clear discontinuities between Oi and Oe horizons and between Oe and $\mathrm{Oa}+\mathrm{A}$ horizon, and the absence of clearcut subdivisions within them, may be explained by threshold levels in the vertical distribution of soil animals and other organisms. We cannot speculate from our data about the 
depth levels at which animals consume litter and defecate at any time of the year, and about all the factors which govern these patterns. Nevertheless, it can be inferred from existing literature that the vertical distribution of soil fauna is determined, among others, by i) genetically fixed behavioural features (Stevenson and Dindal, 1982; Kretzschmar, 1984), ii) ecophysiological requirements of animals (Atalla and Hobart, 1964; Haukka, 1987), iii) the stage of decomposition of litter (Hayes, 1963; Soma and Saitô, 1983; David, 1986). For instance, if we take into account only leaf litter as a food, the depth level at which animals will consume it can be interpreted as a compromise between the need for food of a high nutritional value such as freshly fallen litter (Soma and Saitô, 1983), the toxicity or repellence of some compounds present in undecayed litter (Satchell and Lowe, 1967), and the search for better micro-climate conditions (Joosse, 1971). If we examine diagnostic features of Oi and Oe horizons as ascertained in our analysis (Table 2) it appears that the passage from Oi to Oe horizon is characterized by the deposition of faeces of small litter-consuming animals, such as oribatid mites and enchytraeids, these categories being near absent in the Oi horizon.

The passage from the Oe to the $\mathrm{O} a+\mathrm{A}$ horizon is marked by the appearance of the root system of beech (Table 2). This creates a new discontinuity along the humus profile. According to the humus form, the feeder root system of beech will develop throughout accumulated organo-mineral earthworm faeces (A horizon of mull humus) or holorganic enchytraeid faeces (Oa horizon of moder humus). This common feature is probably the main reason for the absence of a clear distinction between $\mathrm{Oa}$ and $\mathrm{A}$ horizons in the global analysis (Fig. 1). From existing literature, it can be concluded that the vertical distribution of root tips is strongly influenced by humus form horizons and the humus form itself (Meyer and Göttsche, 1971; Persson, 1983; Harvey et al., 1986; Ponge, 1988; Bernier and Ponge, 1994). These results point out that the upper part of the Oa horizon together with the bottom of the Oe horizon is the main micro-site for mycorrhizal root development in moder humus forms, mull humus forms being characterized by a lower number of root tips which are widely distributed throughout the A horizon. Unfortunately mechanisms which could explain these patterns are poorly understood, although the need for available water and nutrients has been advocated as a reason for the preferential development of feeder roots in 
carbon-rich substrates (Persson, 1983).

As this is now well-admitted the genesis of humus form horizons, and thus of humus forms, is placed under the influence of microflora, fauna, and plant subterranean parts, whose activity is determined by climate, parent rock and quantity and quality of vegetation (Kubiëna, 1955; Bal, 1982; Toutain, 1987; Green et al., 1993; Brêthes et al., 1995). The existence of horizons, not for the purpose of classification, but as a discernable entity, with clear emergent properties, can be understood if we take into account the accumulation through time of key categories with a high longevity. This is the case for dead leaves, enchytraeid faeces, earthworm faeces, or fine roots of trees. If a category present in a given horizon has a low longevity, i.e. if it is rapidly transformed into another category or if it disappears from the soil matrix through mineralization or leaching, then it cannot directly participate in the building of this horizon. Rather, it may, i) participate in the building of underlying horizons (for instance colloidal organic compounds precipitating in B horizons), ii) be taken-up by organisms, iii) diffuse in the atmosphere or in the water flow. This is the case, among others, of oribatid faeces which rapidly disappears from the moder profile when consumed by enchytraeids (Ponge, 1991). This is also the case for enchytraeid faeces when ingested in turn by earthworms living in mull humus (Bal, 1982). The passage from one horizon to another should thus be considered as a check in a continuous process (the slow maturation of individual categories in the absence of disturbances), and a start for another continuous process of maturation. The fact that at a given depth level the bulk of categories of a given type are transformed into categories of another type (due to the activity of vertically distributed organisms) will create discontinuities visible to the naked eye and thus will help us to distinguish horizons and humus forms on the field. In the absence of these discontinuities (as between $\mathrm{Oa}$ and $\mathrm{A}$ horizons of moder humus forms) this distinction may be more difficult and field observation may lead to false conclusions, as has been always suggested by Bernier et al. (1993). In this case the identification of horizon components under a dissecting microscope and the use of counting methods (Bernier et al., 1993; Bernier and Ponge, 1994) may help a better characterization of these horizons. 


\section{REFERENCES}

2

5

Atalla, E.A.R., and J. Hobart. 1964. The survival of some soil mites at different humidities and their reaction to humidity gradients. Ent. Exp. Appl. 7: 215-228.

Babel, U. 1971. Gliederung und Beschreibung des Humusprofils in mitteleuropäischen Wäldern. Geoderma 5: 297-324.

Bal, L. 1982. Zoological ripening of soils. PUDOC, Wageningen.

Benzécri, J.P. 1973. L'analyse des données. II. L'analyse des correspondances. Dunod, Paris.

Bernier, N., and J.F. Ponge. 1994. Humus form dynamics during the sylvogenetic cycle in a mountain spruce forest. Soil Biol. Biochem. 26: 183-220.

Bernier, N., J.F. Ponge, and J. André. 1993. Comparative study of soil organic layers in two bilberryspruce forest stands (Vaccinio-Piceetea). Relation to forest dynamics. Geoderma 59: 89-108.

Brady, N.C. 1984. The nature and properties of soils. Macmillan, New York.

Brêthes, A., J.J. Brun, B. Jabiol, J.F. Ponge, and F. Toutain. 1995. Classification of forest humus forms: a French proposal. Ann. Sci. For. 52: 535-546.

David, J.F. 1986. Influence de la durée du séjour dans la litière des feuilles mortes de chêne (Quercus petraea Liebl.) sur leur consommation par le Diplopode Cylindroiulus nitidus (Verhoeff, 1891). C.R. Acad. Sc. Paris, Sér. III 302: 379-381. 
2

9

Delecour, F. 1980. Essai de classification pratique des humus. Pédologie 30: 225-241.

Delecour, F. 1983. Les formes d'humus: identification et description. Natural. Belg. 64: 75-86.

Driessen, P.M., and R. Dudal. 1991. The major soils of the world. Agricultural University of Wageningen, Wageningen, and Catholic University of Leuven, Leuven.

Duchaufour, P. 1997. Pédologie. Sol, végétation, environnement. $5^{\text {th }}$ ed. Masson, Paris.

Federer, C.A. 1982. Subjectivity in the separation of organic horizons of the forest floor. Soil Sci. Soc. Am. J. 46: 1090-1093.

Green, R.N., R.L. Trowbridge, and K. Klinka. 1993. Towards a taxonomic classification of humus forms. For. Sci. Monogr. № 29.

Greenacre, M.J. 1984. Theory and applications of correspondence analysis. Academic Press, London.

Hartmann, F. 1965. Waldhumusdiagnose auf biomorphologischer Grundlage. Springer-Verlag, Wien.

Harvey, A.E., M.F. Jurgensen, M.J. Larsen, and J.A. Schlieter. 1986. Distribution of active ectomycorrhizal short roots in forest soils of the inland Northwest: effects of site and disturbance. USDA Forest Service, Intermountain Research Station, Ogden, Research Paper INT-374.

Haukka, J.K. 1987. Growth and survival of Eisenia fetida (Sav.) (Oligochaeta: Lumbricidae) in relation to temperature, moisture and presence of Enchytraeus albidus (Henle) (Enchytraeidae). Biol. Fertil. Soils 3: 99-102. 
6

Hayes, A.J. 1963. Studies on the feeding preferences of some phthiracarid mites (Acari: Oribatidae). Ent. Exp. Appl. 6: 241-256.

Hesselmann, H. 1926. Studier över barrskogens humustäcke. Meddel. Stat. SkogsförsOksanst. 22: 169552.

Hill, M.O., and H.G. Gauch Jr. 1980. Detrended correspondence analysis: an improved ordination technique. Vegetatio 42: 47-58.

Jabiol, B., A. Brêthes, J.J. Brun, J.F. Ponge, and F. Toutain. 1994. Une classification morphologique et fonctionnelle des formes d'humus. Propositions du référentiel pédologique 1992. Rev. For. Fr. 46: 152-166.

Jabiol, B., A. Brêthes, J.F. Ponge, F. Toutain, and J.J. Brun. 1995. L'humus sous toutes ses formes. ENGREF, Nancy.

Joosse, E.N.G., 1971. Ecological aspects of aggregation in Collembola. Rev. Ecol. Biol. Sol 8: 91-97.

Klinka, K., R.N.Green, R.L. Trowbridge, and L.E. Lowe. 1981. Taxonomic classification of humus forms in ecosystems of British Columbia. First approximation. Land Manag. Rept. № 8.

Kretzschmar, A. 1984. Besoins biologiques des vers de terre et porosité du sol. Bulletin GFHN 15: 96102.

Kubiëna, W.L. 1953. The soils of Europe. Illustrated diagnosis and systematics. CSIC, Madrid, Spain, and Thomas Murby, London. 
9

Kubiëna, W.L. 1955. Animal activity in soils as a decisive factor in establishment of humus forms. p. 73-82 + 2 inlet plates. In D.K. McE. Kevan (ed.) Soil zoology. Butterworths, London.

Meyer, F.H., and D. Göttsche. 1971.Distribution of root tips and tender roots of beech. p. 47-52. In H. Ellenberg (ed.) Ecological studies. Analysis and synthesis, vol. 2. Springer-Verlag, Berlin.

Müller, P.E. 1887. Recherches sur les formes naturelles de l'humus et leur influence sur la végétation et le sol. Ann. Sci. Agron. Fr. Etrang. 6: 85-423 + 7 inlet plates.

Persson, H. 1983. The distribution and productivity of fine roots in boreal forests. Plant Soil 71: 87-101.

Ponge, J.F. 1988. Etude écologique d'un humus forestier par l'observation d'un petit volume, premiers résultats. III. La couche F1 d'un moder sous Pinus sylvestris. Pedobiologia 31: 1-64.

Ponge, J.F. 1991. Succession of fungi and fauna during decomposition of needles in a small area of Scots pine litter. Plant Soil 138: 99-113.

Ponge, J.F., P. Arpin, F. Sondag, and F. Delecour. 1997. Soil fauna and site assessment in beech stands of the Belgian Ardennes. Can. J. For. Res. 27: 2053-2064.

Ponge, J.F., and L. Delhaye. 1995. The hetrogeneity of humus profiles and earthworm communities in a virgin beech forest. Biol. Fertil. Soils 20: 24-32.

Rameau, J.C., D. Mansion, and G. Dumé. 1989. Flore forestière française. Guide écologique illustré. I. Plaines et collines. Institut pour le Développement Forestier, Paris.

Satchell, J.E., and D.G. Lowe. 1967. Selection of leaf litter by Lumbricus terrestris. p. 102-119. In O. Graff 

and J.E. Satchell (ed.) Progress in soil biology. Friedr. Vieweg, Braunschweig, and North-Holland Publishing Company, Amsterdam.

4 Soma, K. and T. Saitô. 1983. Ecological studies of soil organisms with reference to the decomposition of pine needles. II. Litter feeding and breakdown by the woodlouse, Porcellio scaber. Plant Soil 75: 139-151.

7

8 Springett, J.A., J.E.Brittain, and B.P. Springett. 1970. Vertical movement of Enchytraeidae (Oligochaeta) in moorland soils. Oikos 21: 16-21.

10

11 Stevenson, B.G., and D.L. Dindal. 1982. Effect of leaf shape on forest litter spiders: community organization and microhabitat selection of immature Enoplognatha ovata (Clerck) (Theridiidae). J.

14

15 Ter Braak, C.J.F. 1987. The analysis of vegetation-environment relationships by canonical correspondence analysis. Vegetatio 69: 69-77.

17

18 Thill, A., M. Dethioux, and F. Delecour. 1988. Typologie et potentialités forestières des hêtraies naturelles de l'Ardenne Centrale. IRSIA, Brussels.

20

21 Toutain, F. 1987. Activité biologique des sols, modalités et lithodépendance. Biol. Fertil. Soils 3: 31-38.

22

23 Zachariae, G. 1965. Spuren tierischer Tätigkeit im Boden des Buchenwaldes. Forstwiss. Forsch. № 20. 


\section{LEGENDS OF FIGURES}

2

Fig. 1. Results from total correspondence analysis of organic horizons with faunal characteristics in beech forests of the Belgian Ardennes. Projection of horizons (rows) in the plane of axes 1 and 3. Indicated names of horizons were based on field observation and were not included as main variables.

Fig. 2. Partial correspondence analysis on $\mathrm{Oa}$ and $\mathrm{A}$ horizons. Projection of horizons (rows) in the plane of axes 1 and 2. Otherwise as for Fig. 1.

Fig. 3. Partial correspondence analysis on $\mathrm{Oa}$ and $\mathrm{A}$ horizons. Projection of passive variables in the plane of axes 1 and 2. (festuc = Luzulo-Fagetum festucetosum; melic = Melico-Fagetum festucetosum; typic = Luzulo-Fagetum typicum; vaccin = Luzulo-Fagetum vaccinietosum).

Fig. 4. Total correspondence analysis. Projection of animal groups (passive variables) in the plane of axes 1 and 3. Coding of animal groups as in Table 3.

Fig. 5. Partial correspondence analysis on $\mathrm{Oa}$ and $\mathrm{A}$ horizons. Projection of animal groups (passive variables) in the plane of axes 1 and 2. Otherwise as for Fig. 4. 
Table 1. Main features of the 13 studied sites. Phytosociological types according to Thill et al. (1988). Soil types according to FAO-UNESCO classification (Driessen and Dudal 1991). Humus forms according to Brêthes et al. (1995).

\begin{tabular}{lllll}
\hline Site & Altitude & Phytosociological type & Soil type & Humus form \\
\hline $\mathbf{1}$ & $370 \mathrm{~m}$ & Luzulo-Fagetum festucetosum & Dystric cambisol & Dysmull \\
$\mathbf{3}$ & $465 \mathrm{~m}$ & Luzulo-Fagetum festucetosum & Dystric cambisol & Eumoder \\
$\mathbf{4}$ & $500 \mathrm{~m}$ & Luzulo-Fagetum typicum & Dystric cambisol & Dysmoder \\
$\mathbf{5}$ & $505 \mathrm{~m}$ & Luzulo-Fagetum vaccinietesosum & Dystric cambisol & Eumoder to dysmoder \\
$\mathbf{1 6}$ & $\mathbf{4 4 5 \mathrm { m }}$ & Luzulo-Fagetum vaccinietesosum & Dystric cambisol & Eumoder \\
$\mathbf{1 7}$ & $\mathbf{4 3 0 \mathrm { m }}$ & Luzulo-Fagetum typicum & Dystric cambisol & Hemimoder to eumoder \\
$\mathbf{2 2}$ & $\mathbf{4 0 0 \mathrm { m }}$ & Luzulo-Fagetum typicum & Gleyic cambisol & Eumoder to dysmoder \\
$\mathbf{2 4}$ & $390 \mathrm{~m}$ & Luzulo-Fagetum festucetosum & Dystric cambisol & Dysmull to dysmoder \\
$\mathbf{2 6}$ & $430 \mathrm{~m}$ & Luzulo-Fagetum vaccinietesosum & Leptic podzol & Dysmoder \\
$\mathbf{2 8}$ & $375 \mathrm{~m}$ & Luzulo-Fagetum festucetosum & Dystric cambisol & Amphimull to eumoder \\
$\mathbf{4 0}$ & $385 \mathrm{~m}$ & Luzulo-Fagetum vaccinietesosum & Ferric podzol & Dysmoder \\
$\mathbf{1 0 0}$ & $350 \mathrm{~m}$ & Melico-Fagetum festucetosum & Dystric cambisol & Oligomull to dysmull \\
$\mathbf{3 0 7}$ & $380 \mathrm{~m}$ & Luzulo-Fagetum vaccinietesosum & Leptic podzol & Amphimull \\
& & & & \\
\hline
\end{tabular}


Table 2. Most typical categories in the three main groups of horizons depicted by correspondence analysis

Oi

Entire brown leaves of beech

Entire bleached leaves of beech

Intact bud scales of beech

Intact male inflorescences of beech

Entire variegated leaves of beech

Intact twigs

Holorganic faecal material smearing beech leaves

Organo-mineral material smearing beech leaves

Oe

Sandwich material made of beech leaf fragments and holorganic enchytraeid faeces

Brown decaying male inflorescences of beech

Fragments of grass stems browsed by fauna

Pollen

Woodlice shells

Petioles and nerves of beech filled with faeces of phthiracarid oribatid mites

Bud scales of beech, entire but brown and soft

Intact unidentified fragments of seed wings

Intact seed coats of beech

Twigs filled with enchytraeid holorganic faeces

Twigs filled with oribatid holorganic faeces

Living leaf bases of Luzula albida

White rhizomorphs

\section{$\mathrm{Oa}+\mathrm{A}$}

Dead pale yellow creamy mycorrhizae of beech

Sclerotia of Cenoccum geophilum

Intact dead fine long roots of beech

Compacted holorganic enchytraeid faeces

Intact living woody roots of beech

Strongly decayed bud scales of beech

Well-decayed bark fragments

Intact stones

Decaying woody roots of beech

Weathering stones

Charcoal

Dead fine long roots of beech tunnelled by fauna

Decaying grass roots

Dead black mycorrhizae of beech 
Table 3. Mean number of animals which were found during the dissection of humus horizons $(\mathrm{L} \times \mathrm{I} \times \mathrm{h}=5 \times 5 \times 1 \mathrm{~cm})$

\begin{tabular}{|c|c|c|c|c|c|}
\hline & & $\begin{array}{l}\text { Oi } \\
(n=24)\end{array}$ & $\begin{array}{l}\text { Oe } \\
(n=59)\end{array}$ & $\begin{array}{l}\text { Oa } \\
(n=44)\end{array}$ & $\begin{array}{l}A \\
(n=24)\end{array}$ \\
\hline ADB & Adult beetles & 0.02 & 0 & 0.02 & 0 \\
\hline ADF & Adult flies & 0.01 & 0.02 & 0 & 0 \\
\hline ANT & Ants & 0.01 & 0 & 0 & 0 \\
\hline BEE & Beetle larvae (miscellaneous) & 0.14 & 0.3 & 0.09 & 0.04 \\
\hline BOO & Booklice & 0.01 & 0.02 & 0 & 0 \\
\hline CEC & Cecidomyid fly larvae & 0.27 & 0.32 & 0.22 & 0.17 \\
\hline CEN & Centipedes & 0 & 0.06 & 0.09 & 0 \\
\hline CER & Ceratopogonid fly larvae & 0.05 & 0.02 & 0 & 0 \\
\hline CHI & Chironomid fly larvae & 0.25 & 0.3 & 0.64 & 0.25 \\
\hline CLI & Click-beetle larvae & 0.06 & 0.03 & 0.19 & 0.04 \\
\hline $\mathrm{COC}$ & Cochineals & 0.01 & 0.11 & 0 & 0 \\
\hline COP & Copepods & 0.04 & 0.01 & 0 & 0 \\
\hline DIP & Diplura & 0.14 & 0.21 & 0.15 & 0.08 \\
\hline DOL & Dolichopodid-empidid fly larvae & 0.02 & 0.21 & 0.28 & 0.33 \\
\hline EAR & Earthworms & 0.07 & 0.01 & 0.19 & 0 \\
\hline ENC & Enchytraeids & 12 & 113 & 231 & 50 \\
\hline FLY & Fly larvae (miscellaneous) & 0.02 & 0.11 & 0.06 & 0.04 \\
\hline MIL & Millipeds & 0 & 0 & 0 & 0.04 \\
\hline MIT & Mites (miscellaneous) & 10 & 19 & 10 & 2 \\
\hline ORI & Oribatid mites (miscellaneous) & 10 & 20 & 14 & 2 \\
\hline PAU & Pauropods & 0.37 & 0.48 & 0.64 & 0.08 \\
\hline PHT & Phthiracarid oribatid mites & 2 & 24 & 8 & 1 \\
\hline PLA & Platynothrus peltifer (oribatid mite) & 6.9 & 4.9 & 3.5 & 0.5 \\
\hline PRO & Protura & 0 & 0.01 & 0.2 & 0.17 \\
\hline PSE & Pseudoscorpions & 0.06 & 0 & 0 & 0.04 \\
\hline SCl & Sciarid fly larvae & 1.5 & 4.8 & 4.4 & 0.5 \\
\hline SLU & Slugs & 0.07 & 0 & 0 & 0 \\
\hline SPI & Spiders & 0.17 & 0.25 & 0.06 & 0 \\
\hline SPR & Springtails & 14 & 64 & 52 & 17 \\
\hline SYM & Symphiles & 0.1 & 0.17 & 0.34 & 0.13 \\
\hline THR & Thrips & 0.02 & 0.02 & 0 & 0 \\
\hline TIP & Tipulid fly larvae & 0.02 & 0.02 & 0 & 0 \\
\hline WOO & Woodlice & 0.05 & 0.01 & 0 & 0 \\
\hline
\end{tabular}


Appendix 1. Categories used for the description of humus horizons. Coordinates on factorial axes 1 and 3 of total correspondence analysis

\begin{tabular}{|c|c|c|}
\hline Categories & Axis 1 & Axis 3 \\
\hline Entire brow $\mathrm{n}$ leaves of beech & -0.0280 & -0.0142 \\
\hline Bundles of entire brow $n$ leaves of beech & -0.0114 & -0.0058 \\
\hline Brow $n$ leaves of beech skeletonized by macrofauna & -0.0140 & 0.0020 \\
\hline Bundles of brow $\mathrm{n}$ leaves of beech skeletonized by macrofauna & -0.0124 & 0.0011 \\
\hline Brow $n$ leaves of beech skeletonized by mesofauna & -0.0085 & -0.0056 \\
\hline Bundles of brow $n$ leaves of beech skeletonized by mesofauna & -0.0065 & -0.0035 \\
\hline Entire variegated leaves of beech & -0.0219 & -0.0146 \\
\hline Bundles of entire variegated leaves of beech & -0.0146 & -0.0078 \\
\hline Entire variegated leaves of beech skeletonized by macrofauna & -0.0050 & -0.0013 \\
\hline Entire variegated leaves of beech skeletonized by mesofauna & -0.0077 & 0.0018 \\
\hline Bundles of variegated leaves of beech skeletonized by macrofauna & -0.0045 & 0.0030 \\
\hline Entire bleached leaves of beech & -0.0265 & -0.0108 \\
\hline Bundles of entire bleached leaves of beech & -0.0143 & -0.0066 \\
\hline Bleached leaves of beech skeletonized by macrofauna & -0.0160 & 0.0090 \\
\hline Bundles of bleached leaves of beech skeletonized by macrofauna & -0.0131 & 0.0048 \\
\hline Bleached leaves of beech skeletonized by mesofauna & -0.0149 & 0.0028 \\
\hline Bundles of bleached leaves of beech skeletonized by mesofauna & -0.0106 & -0.0083 \\
\hline Pits done by caterpillars in beech leaves & -0.0115 & -0.0017 \\
\hline Nests done by foliage-consuming insects & -0.0085 & -0.0073 \\
\hline Organo-mineral material smearing beech leaves & -0.0184 & -0.0128 \\
\hline Holorganic faecal material smearing beech leaves & -0.0216 & -0.0035 \\
\hline Intact petioles and nerves of beech & -0.0022 & 0.0027 \\
\hline Petioles and nerves of beech tunnelled by fauna & 0.0001 & 0.0092 \\
\hline Petioles and nerves of beech filled with enchytraeid faeces & -0.0084 & 0.0045 \\
\hline Petioles and nerves of beech filled with faeces of Adoristes ovatus (oribatid mite) & -0.0045 & 0.0030 \\
\hline Petioles and nerves of beech filled $w$ ith faeces of phthiracarid oribatid mites & -0.0025 & 0.0188 \\
\hline Petioles and nerves of beech filled w ith faeces of sciarid dipteran larvae & -0.0014 & 0.0091 \\
\hline Petioles and nerves of beech filled $w$ ith grass roots & -0.0045 & 0.0030 \\
\hline Petioles and nerves of beech brow $n$ and tough & -0.0112 & -0.0027 \\
\hline Petioles and nerves of beech bleached & -0.0018 & 0.0009 \\
\hline Sandw ich material made of beech leaf fragments and holorganic enchytraeid faeces & 0.0039 & 0.0250 \\
\hline Sandw ich material made of beech leaf fragments and holorganic earthw orm faeces & -0.0045 & 0.0034 \\
\hline Sandw ich material made of beech leaf fragments and holorganic oribatid faeces & 0.0033 & 0.0106 \\
\hline Sandw ich material made of beech leaf fragments and organo-mineral earthw orm faeces & -0.0003 & 0.0024 \\
\hline Sandw ich material made of beech leaf fragments and organo-mineral enchytraeid faeces & 0.0037 & -0.0025 \\
\hline Sandw ich material made of beech leaf fragments and holorganic sciarid faeces & 0.0001 & -0.0007 \\
\hline Skeletonized beech leaf fragments & 0.0098 & -0.0046 \\
\hline Bundles of skeletonized beech leaf fragments & 0.0055 & 0.0060 \\
\hline Brow $n$ beech leaf fragments untouched by fauna & 0.0141 & -0.0019 \\
\hline Intact bud scales of beech & -0.0299 & -0.0037 \\
\hline Bud scales of beech, entire but brow $n$ and soft & 0.0008 & 0.0191 \\
\hline Strongly decayed bud scales of beech & 0.0217 & -0.0043 \\
\hline Intact male inflorescences of beech & -0.0232 & -0.0120 \\
\hline Brow $n$ decaying male inflorescences of beech & -0.0057 & 0.0236 \\
\hline Pollen mass & -0.0022 & 0.0204 \\
\hline Intact seed coats of beech & 0.0038 & 0.0175 \\
\hline Seed coats of beech tunnelled by phthiracarid mites & 0.0006 & 0.0077 \\
\hline Seed coats of beech tunnelled by enchytraeids & 0.0051 & 0.0037 \\
\hline Seed coats of beech tunnelled by sciarid larvae & -0.0009 & 0.0025 \\
\hline Seed coats of beech penetrated by roots & 0.0028 & 0.0004 \\
\hline Intact fragments of beech burr & -0.0098 & 0.0019 \\
\hline Soft fragments of beech burr & 0.0099 & 0.0028 \\
\hline Soft fragments of beech burr tunnelled by oribatid mites & 0.0025 & 0.0108 \\
\hline Soft fragments of beech burr tunnelled by enchytraeids & 0.0068 & 0.0069 \\
\hline Soft fragments of beech burr tunnelled by sciarid larvae & 0.0029 & 0.0069 \\
\hline Soft fragments of beech burr tunnelled by springtails & 0.0012 & 0.0043 \\
\hline Soft fragments of beech burr penetrated by grass roots & 0.0033 & -0.0048 \\
\hline Beech cupules tunnelled by fauna & 0.0006 & -0.0024 \\
\hline Intact beech gallnuts & 0.0051 & 0.0010 \\
\hline Intact twigs & -0.0225 & -0.0033 \\
\hline Tw igs decayed by w hite-rot & -0.0087 & -0.0031 \\
\hline Tw ig fragments tunnelled by fauna & -0.0074 & 0.0106 \\
\hline Bark remnants of twigs & 0.0079 & 0.0072 \\
\hline Tw igs filled w ith enchytraeid holorganic faeces & 0.0115 & 0.0205 \\
\hline Twigs filled w ith enchytraeid organo-mineral faeces & 0.0102 & -0.0024 \\
\hline Tw igs filled w ith sciarid holorganic faeces & 0.0015 & 0.0101 \\
\hline Tw igs filled w ith oribatid holorganic faeces & 0.0085 & 0.0138 \\
\hline Twigs penetrated by beech roots & 0.0129 & 0.0009 \\
\hline
\end{tabular}


Appendix 1. Continued

\begin{tabular}{|c|c|c|}
\hline Categories & Axis 1 & Axis 3 \\
\hline Intact w ood fragments & -0.0048 & -0.0029 \\
\hline Decayed w ood fragments & 0.0016 & -0.0093 \\
\hline Wood fragments tunnelled by fauna & 0.0096 & 0.0036 \\
\hline Wood fragments penetrated by grass roots & -0.0045 & 0.0030 \\
\hline Wood fragments penetrated by beech fine roots & 0.0025 & -0.0063 \\
\hline Intact bark fragments & 0.0072 & -0.0060 \\
\hline Well-decayed bark fragments & 0.0179 & -0.0147 \\
\hline Bark fragments tunnelled by enchytraeids & -0.0018 & 0.0094 \\
\hline Bark fragments tunnelled by phthiracarid mites & 0.0001 & 0.0075 \\
\hline Bark fragments tunnelled by sciarid larvae & -0.0022 & 0.0046 \\
\hline Bark fragments penetrated by grass roots & -0.0045 & 0.0030 \\
\hline Intact living fine long roots of beech & 0.0231 & 0.0184 \\
\hline Living fine long roots of beech brow sed by fauna & 0.0123 & -0.0061 \\
\hline Intact dead fine long roots of beech & 0.0238 & -0.0178 \\
\hline Dead fine long roots of beech tunnelled by fauna & 0.0145 & -0.0119 \\
\hline Dead fine long roots of beech penetrated by grass roots & 0.0031 & -0.0069 \\
\hline Dead fine long roots of beech, voided & 0.0046 & -0.0075 \\
\hline Living w oody roots of beech & 0.0237 & -0.0031 \\
\hline Living w oody roots of beech brow sed by fauna & 0.0069 & -0.0058 \\
\hline Decaying w oody roots of beech & 0.0160 & -0.0133 \\
\hline Living pale yellow creamy mycorrhizae of beech & 0.0221 & 0.0136 \\
\hline Pale yellow creamy mycorrhizae of beech brow sed by fauna & 0.0181 & 0.0003 \\
\hline Dead pale yellow creamy mycorrhizae of beech & 0.0260 & -0.0139 \\
\hline Living orange brow $n$ mycorrhizae of beech $w$ ith w oolly mycelium & 0.0106 & 0.0078 \\
\hline Orange brow $\mathrm{n}$ mycorrhizae of beech $\mathrm{w}$ ith w oolly mycelium brow sed by fauna & 0.0016 & 0.0018 \\
\hline Dead orange brow $n$ mycorrhizae of beech w ith w oolly mycelium & 0.0128 & -0.0068 \\
\hline Living black mycorrhizae of beech (produced by Cenoccum geophilum) & 0.0181 & 0.0104 \\
\hline Living black mycorrhizae of beech brow sed by fauna & 0.0019 & 0.0043 \\
\hline Dead black mycorrhizae of beech & 0.0141 & -0.0087 \\
\hline Living yellow mycorrhizae of beech with w oolly mycelium & 0.0028 & 0.0074 \\
\hline Living shoots of Polytrichum formosum & -0.0067 & 0.0087 \\
\hline Fragments of stems of Polytrichum formosum, red and tough & 0.0032 & 0.0044 \\
\hline Fragments of stems of Polytrichum formosum, voided & 0.0051 & 0.0095 \\
\hline Dead stem bases of Polytrichum formosum & 0.0024 & -0.0001 \\
\hline Decaying stem bases of Polytrichum formosum & 0.0047 & -0.0024 \\
\hline Living shoots of Scleropodium purum & -0.0073 & 0.0111 \\
\hline Dead shoots of Scleropodium purum & 0.0042 & 0.0043 \\
\hline Living shoots of Leucobryum glaucum & -0.0064 & -0.0054 \\
\hline Dead shoots of Leucobryum glaucum & 0.0003 & -0.0012 \\
\hline Dead moss, undetermined & -0.0057 & -0.0035 \\
\hline Intact leaves of Luzula forsteri & -0.0060 & -0.0057 \\
\hline Bleached leaves of Luzula forsteri & -0.0034 & -0.0070 \\
\hline Living leaf bases of Luzula forsteri & 0.0000 & 0.0136 \\
\hline Decaying leaf bases of Luzula forsteri & 0.0047 & -0.0024 \\
\hline Intact leaves of Deschampsia flexuosa & -0.0074 & -0.0030 \\
\hline Decaying leaves of Deschampsia flexuosa & -0.0135 & 0.0017 \\
\hline Living leaf bases of Deschampsia flexuosa & -0.0037 & -0.0003 \\
\hline Decaying leaf bases of Deschampsia flexuosa & 0.0120 & -0.0012 \\
\hline Intact inflorescences of Deschampsia flexuosa & -0.0058 & -0.0045 \\
\hline Decaying inflorescences of Deschampsia flexuosa & -0.0098 & -0.0003 \\
\hline Living grass roots & 0.0090 & -0.0022 \\
\hline Decaying grass roots & 0.0144 & -0.0083 \\
\hline Intact grass stems & 0.0008 & -0.0136 \\
\hline Fragments of grass stems brow sed by fauna & -0.0022 & 0.0204 \\
\hline Fragments of decaying grass roots & -0.0062 & -0.0026 \\
\hline Intact leaves of Vaccinium myrtillus & -0.0075 & -0.0063 \\
\hline Skeletonized leaves of Vaccinium myrtillus & -0.0101 & -0.0034 \\
\hline Roots of Vaccinium myrtillus & 0.0053 & 0.0013 \\
\hline Living rhizomes of Vaccinium myrtillus & 0.0016 & 0.0018 \\
\hline Decaying rhizomes of Vaccinium myrtillus & 0.0072 & -0.0001 \\
\hline Bleached leaves of Oxalis acetosella & 0.0013 & -0.0039 \\
\hline Brow $n$ entire leaves of Acer pseudoplatanus & -0.0051 & -0.0198 \\
\hline Brow $\mathrm{n}$ leaves of Acer pseudoplatanus skeletonized by macrofauna & -0.0051 & -0.0198 \\
\hline Bleached leaves of Acer pseudoplatanus & -0.0053 & -0.0192 \\
\hline Bleached leaves of Acer pseudoplatanus skeletonized by macrofauna & -0.0051 & -0.0198 \\
\hline Leaves of Acer pseudoplatanus skeletonized by mesofauna & -0.0018 & -0.0002 \\
\hline
\end{tabular}

$$
\text { Continued. }
$$


Appendix 1. Continued

\begin{tabular}{|c|c|c|}
\hline Categories & Axis 1 & Axis 3 \\
\hline Winged seed of Acer pseudoplatanus w ith intact w ing & 0.0001 & -0.0007 \\
\hline Winged seed of Acer pseudoplatanus w ith skeletonized wing & -0.0062 & 0.0030 \\
\hline Wingless seed of Acer pseudoplatanus & -0.0012 & 0.0051 \\
\hline Winged seed of Fraxinus excelsior $w$ ith intact $w$ ing & -0.0053 & -0.0192 \\
\hline Brow $n$ entire leaves of Quercus petraea & -0.0076 & -0.0067 \\
\hline Leaves of Quercus petraea skeletonized by mesofauna & -0.0049 & -0.0013 \\
\hline Intact unidentified fragments of seed w ings & -0.0050 & 0.0176 \\
\hline Skeletonized unidentified fragments of seed w ings & -0.0027 & 0.0036 \\
\hline Brow $\mathrm{n}$ entire needles of Picea abies & -0.0010 & -0.0002 \\
\hline Bleached entire needles of Picea abies & -0.0108 & -0.0034 \\
\hline Needles of Picea abies brow sed by fauna & -0.0002 & 0.0086 \\
\hline Seed w ings of Picea abies & -0.0053 & -0.0032 \\
\hline Brow $\mathrm{n}$ rhizomorphs & -0.0047 & 0.0075 \\
\hline White rhizomorphs & -0.0023 & 0.0130 \\
\hline Yellow rhizomorphs & 0.0028 & 0.0074 \\
\hline Dead rhizomorphs of Armillaria & 0.0100 & -0.0074 \\
\hline Dead rhizomorphs of Armillaria tunnelled by fauna & 0.0100 & -0.0074 \\
\hline Sclerotia of Cenoccum geophilum & 0.0245 & -0.0136 \\
\hline Lichens & -0.0090 & -0.0053 \\
\hline Intact caterpillar faeces & -0.0137 & 0.0099 \\
\hline Caterpillar faeces tunnelled by phthiracarid mites & 0.0056 & 0.0078 \\
\hline Intact slug faeces & -0.0142 & -0.0045 \\
\hline Slug faeces tunnelled by enchytraeids & -0.0089 & -0.0049 \\
\hline Slug faeces tunnelled by sciarid larvae & -0.0089 & -0.0049 \\
\hline Intact holorganic earthw orm faeces & -0.0124 & 0.0118 \\
\hline Holorganic earthw orm faeces tunnelled by enchytraeids & 0.0007 & 0.0057 \\
\hline Unidentified holorganic faeces & -0.0056 & -0.0037 \\
\hline Intact organo-mineral earthw orm faeces & -0.0025 & 0.0036 \\
\hline Compacted organo-mineral earthw orm faeces & 0.0088 & -0.0016 \\
\hline Organo-mineral earthw orm faeces tunnelled by enchytraeids & 0.0042 & 0.0034 \\
\hline Holorganic w oodlice faeces & -0.0120 & 0.0033 \\
\hline Holorganic milliped faeces & 0.0048 & 0.0049 \\
\hline Holorganic milliped faeces tunnelled by enchytraeids & 0.0036 & 0.0010 \\
\hline Holorganic milliped faeces tunnelled by phthiracarid mites & 0.0036 & 0.0010 \\
\hline Holorganic cranefly faeces & 0.0004 & 0.0048 \\
\hline Intact holorganic sciarid faeces & -0.0044 & -0.0007 \\
\hline Compacted holorganic sciarid faeces & 0.0074 & -0.0069 \\
\hline Intact holorganic enchytraeid faeces & 0.0141 & 0.0081 \\
\hline Compacted holorganic enchytraeid faeces & 0.0219 & -0.0120 \\
\hline Organo-mineral enchytraeid faeces & 0.0078 & -0.0044 \\
\hline Compacted organo-mineral enchytraeid faeces & 0.0070 & -0.0117 \\
\hline Compacted organic-dominant organo-mineral material & 0.0066 & -0.0064 \\
\hline Compacted organo-mineral material & 0.0114 & -0.0120 \\
\hline Compacted mineral-dominant organo-mineral material & 0.0040 & -0.0085 \\
\hline Unidentified mineral assemblages & -0.0016 & -0.0011 \\
\hline Charcoal & 0.0132 & -0.0153 \\
\hline Snail shells & -0.0028 & 0.0098 \\
\hline Woodlice shells & -0.0022 & 0.0204 \\
\hline Intact stones & 0.0161 & -0.0103 \\
\hline Weathering stones & 0.0147 & -0.0128 \\
\hline Weathering stones impregnated with organic matter & 0.0048 & -0.0096 \\
\hline
\end{tabular}


Appendix 2. Categories used for the description of humus horizons. Coordinates on factorail axes 1 and 2 of partial correspondence analysis $(\mathrm{OH}$ and $\mathrm{A})$.

\section{Categories}

Brown leaves of beech skeletonized by macrofauna Bleached leaves of beech skeletonized by macrofauna

Bleached leaves of beech skeletonized by mesofauna

Intact petioles and nerves of beech

Petioles and nerves of beech tunnelled by fauna

Petioles and nerves of beech filled with enchytraeid faeces

Petioles and nerves of beech filled with faeces of phthiracarid oribatid mites

Sandwich material made of beech leaf fragments and holorganic enchytraeid faeces

Sandwich material made of beech leaf fragments and holorganic earthworm faeces

Sandwich material made of beech leaf fragments and holorganic oribatid faeces

Sandwich material made of beech leaf fragments and organo-mineral earthworm faeces

Sandwich material made of beech leaf fragments and organo-mineral enchytraeid faeces Skeletonized beech leaf fragments

Bundles of skeletonized beech leaf fragments

Brown beech leaf fragments untouched by fauna

Intact bud scales of beech

Bud scales of beech, entire but brown and soft

Strongly decayed bud scales of beech

Brown decaying male inflorescences of beech

Intact seed coats of beech

Seed coats of beech tunnelled by phthiracarid mites

Seed coats of beech tunnelled by enchytraeids

Intact fragments of beech burr

Soft fragments of beech burr

Soft fragments of beech burr tunnelled by oribatid mites

Soft fragments of beech burr tunnelled by enchytraeids

Beech cupules tunnelled by fauna

Twigs decayed by white-rot

Twig fragments tunnelled by fauna

Bark remnants of twigs

Twigs filled with enchytraeid holorganic faeces

Twigs filled with enchytraeid organo-mineral faeces

Twigs filled with sciarid holorganic faeces

Twigs filled with oribatid holorganic faeces

Twigs penetrated by beech roots

Decayed wood fragments

Wood fragments tunnelled by fauna

Wood fragments penetrated by beech fine roots

Intact bark fragments

Well-decayed bark fragments

Bark fragments tunnelled by enchytraeids

Bark fragments tunnelled by phthiracarid mites

Intact living fine long roots of beech

Living fine long roots of beech browsed by fauna

Intact dead fine long roots of beech

Dead fine long roots of beech tunnelled by fauna

Dead fine long roots of beech penetrated by grass roots

Dead fine long roots of beech, voided

Living woody roots of beech

Living woody roots of beech browsed by fauna

Decaying woody roots of beech

Living pale yellow creamy mycorrhizae of beech

Pale yellow creamy mycorrhizae of beech browsed by fauna

Dead pale yellow creamy mycorrhizae of beech

Living orange brown mycorrhizae of beech with woolly mycelium

Dead orange brown mycorrhizae of beech with woolly mycelium

Living black mycorrhizae of beech (produced by Cenoccum geophilum)

Dead black mycorrhizae of beech

Living shoots of Polytrichum formosum

Fragments of stems of Polytrichum formosum, voided

Dead stem bases of Polytrichum formosum

Dead shoots of Leucobryum glaucum

Bleached leaves of Luzula forsteri

Living leaf bases of Luzula forsteri

\section{Continued}

\begin{tabular}{rr} 
Axis 1 & Axis 2 \\
\hline-0.0002 & -0.0319 \\
-0.0002 & -0.0319 \\
-0.0002 & -0.0319 \\
-0.0130 & -0.0013 \\
-0.0100 & 0.0135 \\
-0.0051 & 0.0069 \\
-0.0094 & -0.0090 \\
-0.0343 & 0.0089 \\
-0.0054 & -0.0001 \\
-0.0383 & -0.0025 \\
-0.0031 & -0.0038 \\
-0.0002 & -0.0008 \\
0.0047 & 0.0114 \\
0.0002 & 0.0201 \\
-0.0051 & -0.0081 \\
-0.0214 & -0.0201 \\
-0.0292 & -0.0056 \\
0.0016 & 0.0205 \\
-0.0246 & 0.0038 \\
-0.0105 & 0.0065 \\
0.0020 & 0.0054 \\
-0.0015 & 0.0051 \\
-0.0152 & -0.0048 \\
0.0041 & 0.0022 \\
-0.0106 & 0.0136 \\
0.0012 & 0.0197 \\
0.0051 & 0.0050 \\
0.0000 & -0.0066 \\
-0.0013 & 0.0229 \\
0.0008 & -0.0122 \\
-0.0119 & 0.0159 \\
-0.0289 & -0.0002 \\
0.0002 & 0.0068 \\
-0.0287 & 0.0078 \\
-0.0294 & 0.0045 \\
0.0010 & -0.0055 \\
-0.0168 & -0.0104 \\
0.0024 & -0.0066 \\
-0.0140 & 0.0038 \\
0.0091 & 0.0086 \\
-0.0090 & 0.0079 \\
-0.0022 & -0.0101 \\
-0.0212 & -0.0033 \\
-0.0021 & 0.0103 \\
0.0061 & -0.0014 \\
0.0045 & 0.0073 \\
0.00010 & -0.0025 \\
0.0037 & -0.0105 \\
-0.0012 & -0.0043 \\
-0.0012 & -0.0063 \\
0.0045 & -0.0002 \\
\hline 0.0047 & -0.0033 \\
0.0028 & 0.0182 \\
0.0040 & 0.0103 \\
0.0113 & 0.0113 \\
-0.0172 & -0.0035 \\
-0.0016 & 0.0125 \\
0.0040 & 0.0047 \\
0.0052 & 0.0069 \\
\hline & 0.0065 \\
\hline
\end{tabular}


Appendix 2. Continued

\begin{tabular}{|c|c|c|}
\hline Categories & Axis 1 & Axis 2 \\
\hline Decaying leaf bases of Luzula forsteri & 0.0037 & -0.0076 \\
\hline Decaying leaves of Deschampsia flexuosa & -0.0268 & 0.0051 \\
\hline Living leaf bases of Deschampsia flexuosa & 0.0045 & -0.0002 \\
\hline Decaying leaf bases of Deschampsia flexuosa & 0.0066 & 0.0079 \\
\hline Living grass roots & 0.0065 & -0.0133 \\
\hline Decaying grass roots & 0.0085 & -0.0002 \\
\hline Intact grass stems & 0.0026 & -0.0070 \\
\hline Roots of Vaccinium myrtillus & -0.0053 & 0.0095 \\
\hline Decaying rhizomes of Vaccinium myrtillus & -0.0014 & 0.0092 \\
\hline Bleached leaves of Oxalis acetosella & -0.0002 & -0.0319 \\
\hline Brown entire needles of Picea abies & -0.0145 & 0.0016 \\
\hline Brown rhizomorphs & 0.0010 & -0.0071 \\
\hline White rhizomorphs & -0.0140 & 0.0071 \\
\hline Dead rhizomorphs of Armillaria & -0.0012 & 0.0015 \\
\hline Dead rhizomorphs of Armillaria tunnelled by fauna & -0.0012 & 0.0015 \\
\hline Sclerotia of Cenoccum geophilum & 0.0012 & 0.0035 \\
\hline Intact caterpillar faeces & -0.0006 & 0.0123 \\
\hline Intact holorganic earthworm faeces & 0.0018 & -0.0039 \\
\hline Holorganic earthworm faeces tunnelled by enchytraeids & -0.0383 & -0.0025 \\
\hline Intact organo-mineral earthworm faeces & 0.0031 & -0.0265 \\
\hline Compacted organo-mineral earthworm faeces & -0.0040 & -0.0140 \\
\hline Organo-mineral earthworm faeces tunnelled by enchytraeids & 0.0009 & -0.0076 \\
\hline Holorganic milliped faeces & -0.0017 & -0.0222 \\
\hline Holorganic milliped faeces tunnelled by enchytraeids & -0.0383 & -0.0025 \\
\hline Holorganic milliped faeces tunnelled by phthiracarid mites & -0.0383 & -0.0025 \\
\hline Holorganic cranefly faeces & -0.0020 & -0.0009 \\
\hline Compacted holorganic sciarid faeces & 0.0059 & 0.0109 \\
\hline Intact holorganic enchytraeid faeces & -0.0083 & 0.0060 \\
\hline Compacted holorganic enchytraeid faeces & 0.0109 & 0.0235 \\
\hline Organo-mineral enchytraeid faeces & -0.0068 & 0.0034 \\
\hline Compacted organo-mineral enchytraeid faeces & 0.0103 & -0.0041 \\
\hline Compacted organic-dominant organo-mineral material & 0.0034 & -0.0035 \\
\hline Compacted organo-mineral material & 0.0070 & -0.0078 \\
\hline Compacted mineral-dominant organo-mineral material & 0.0048 & -0.0048 \\
\hline Unidentified mineral assemblages & 0.0051 & 0.0050 \\
\hline Charcoal & 0.0063 & -0.0200 \\
\hline Intact stones & 0.0036 & -0.0269 \\
\hline Weathering stones & 0.0092 & -0.0065 \\
\hline Weathering stones impregnated with organic matter & 0.0077 & -0.0002 \\
\hline
\end{tabular}




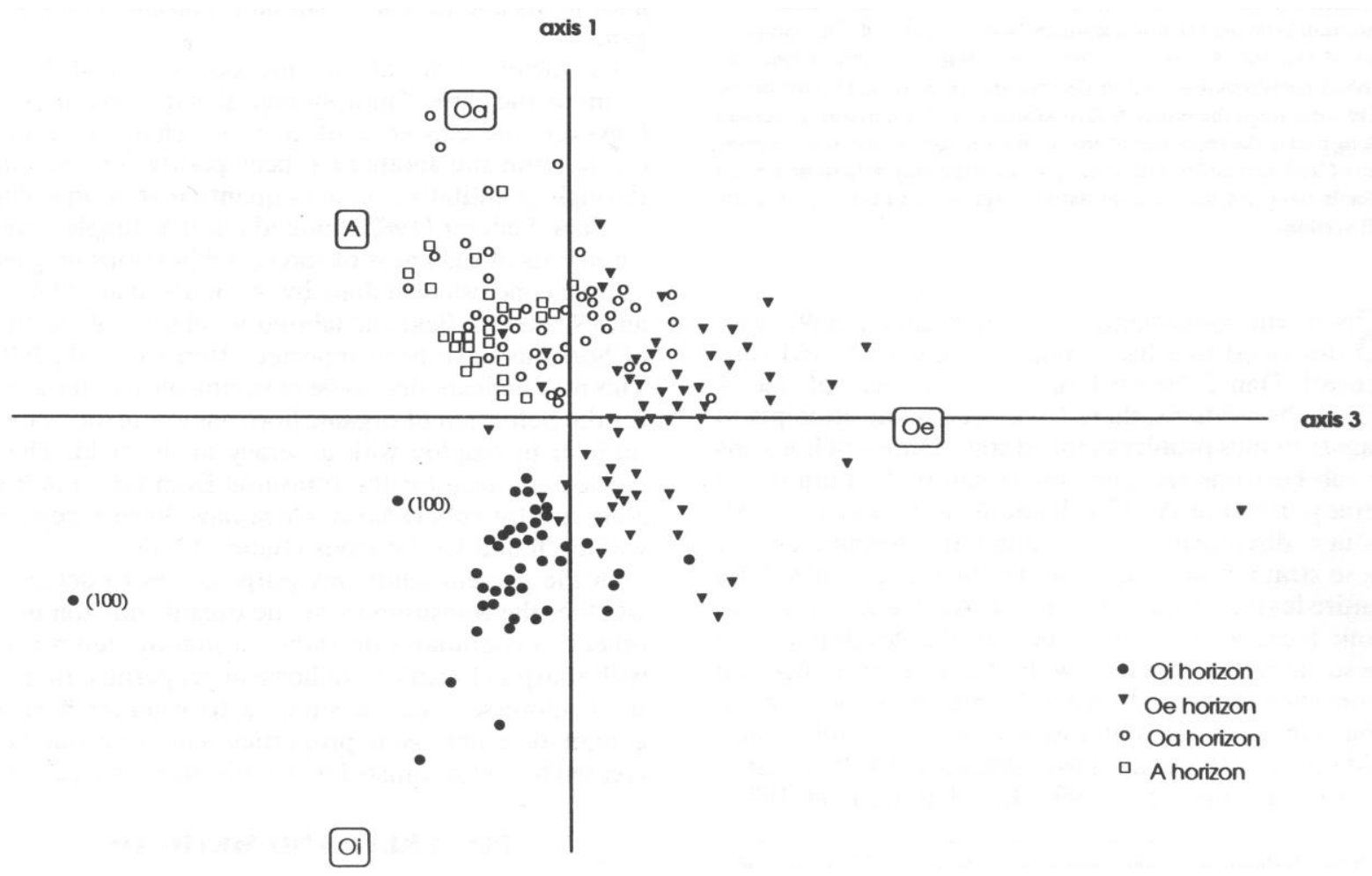

$3 \quad$ Fig. 1 


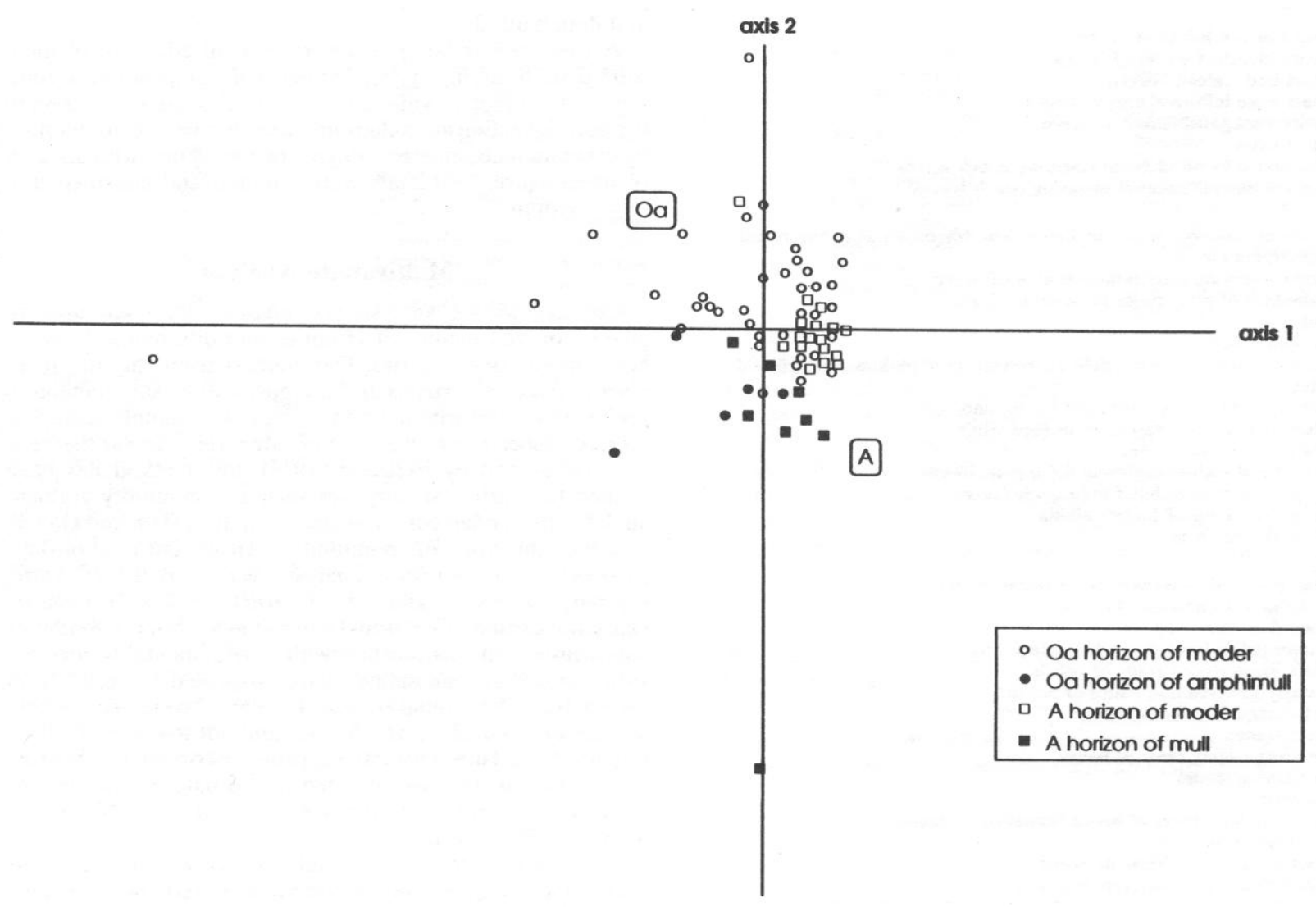

$3 \quad$ Fig. 2 


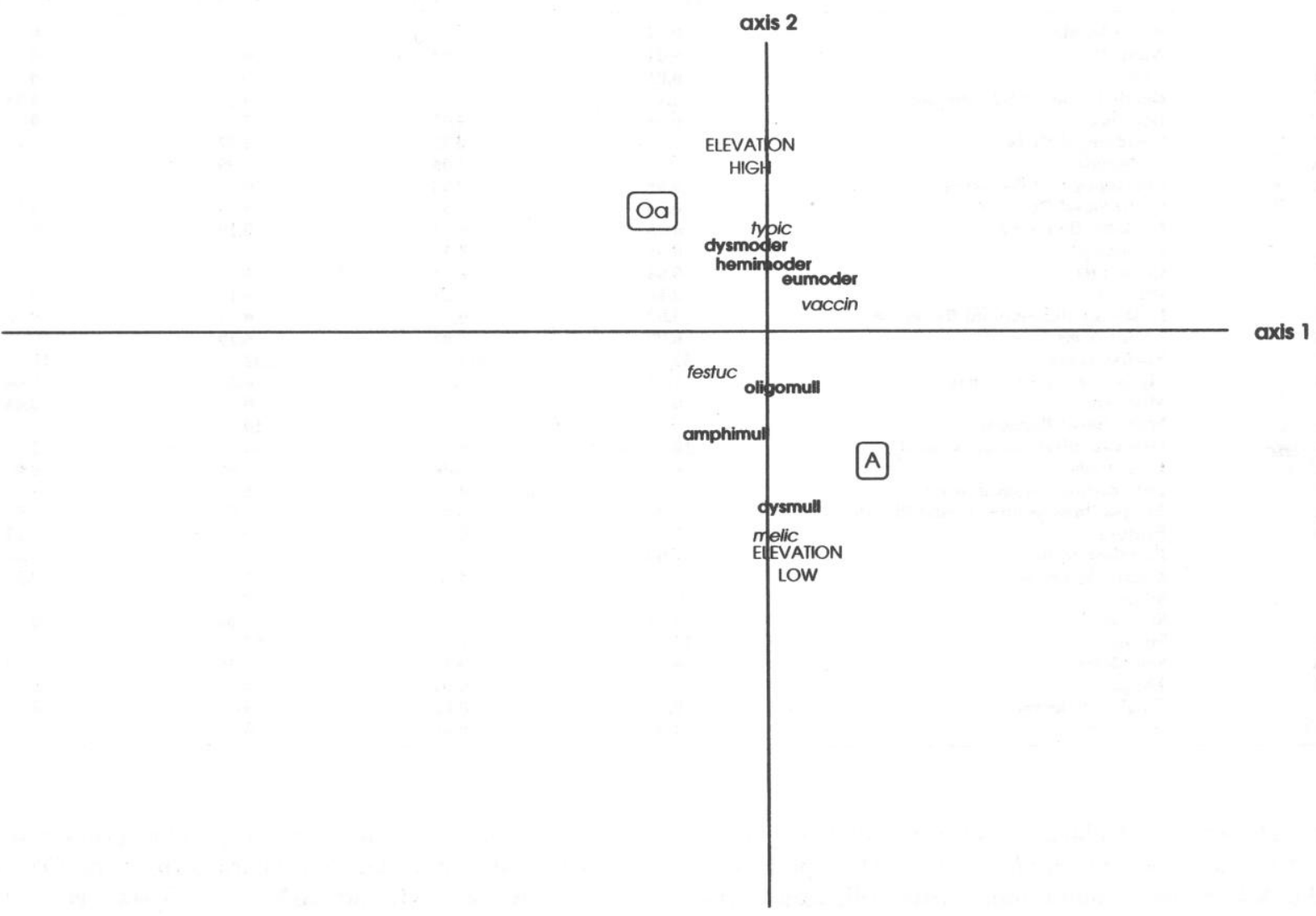

2

$3 \quad$ Fig. 3 


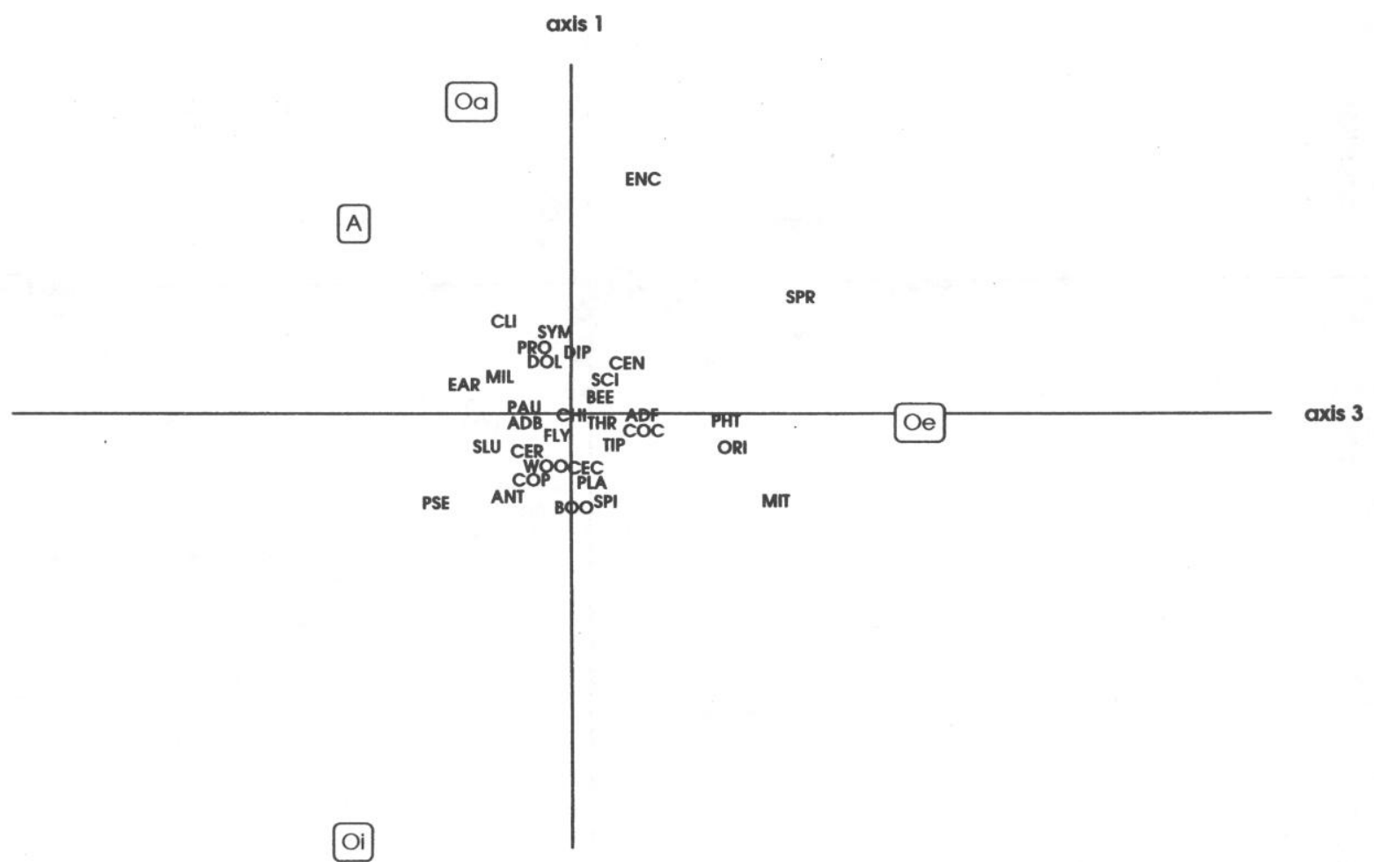

2

$3 \quad$ Fig. 4 
36

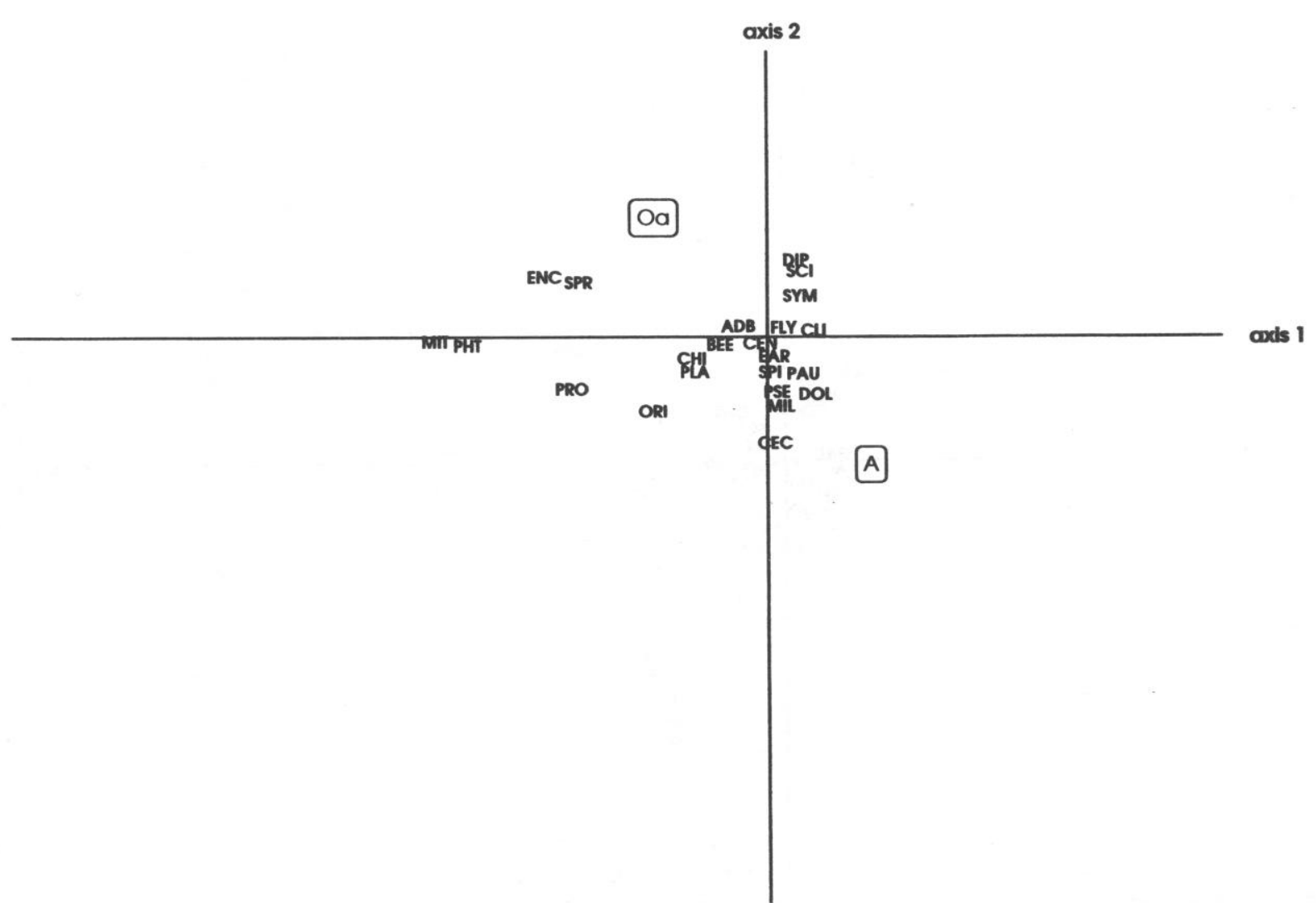

2

$3 \quad$ Fig. 5 